\title{
Crushed Rocks and Dimension Stone: Exploration, Evaluation and Exploitation in parts of Igarra Area, Southwestern Nigeria
}

\begin{abstract}
N. Egesi ${ }^{1}$, J. I. Nwosu ${ }^{1}$
${ }^{1}$ Department of Geology, Faculty of Science, University of Port Harcourt, Port Harcourt, Nigeria

Abstract: The study area (Igarra) has been variously studied and is still receiving attention from workers on basement geology. Some investors in the quarry industry still make error in the selection of site for development and production of crushed rocks and dimension stone. The Octopol quarry in Igarra area was abandoned largely due to scanty information on the mineralogy of the schist quarried to ascertain the quality of the rock. However, granites, granite gneisses, charnockites and marbles present in the area can be suitable for dimension stone production. The marble should not be cleaned with wet cloth as the water will react with the rock to form a weak acid which attacks the polished surface and decolourize it to a dull and uninteresting surface. There is need to involve geoscientists in dimension stone site selection and production to ensure that proper rock is chosen, and also for quality control as mining progress rock quality varies.
\end{abstract}

Keywords: Crushed rocks/Dimension Stone, Site Selection, Quarry Industry, Igarra Area, Southwest Nigeria

\section{INTRODUCTION}

The Igarra area is part of the Precambrian Basement Complex of Southwestern Nigeria. It is located between latitude $07^{\circ} 15^{\prime}$ to $07^{\circ} 30^{\prime} \mathrm{N}$ and longitude $006^{\circ} 00^{\prime}$ to $006^{\circ} 15^{\prime} \mathrm{E}$. The major highway in the area runs from south to north Auchi, Ikpeshi, Agor, Igarra, Ibillo, Lankpeshi, Ogori/Magongo, to Okene and Okene, Ukpella, Uzaurie, Auchi axis to the south. The area has been mapped by several workers including Jones and Hockey (1964), Odeyemi (1976), Geolgical Survey of Nigeria GSN, (1986) and Annor (1998), and students from Universities across Nigeria. The major rock units are migmatites-gneiss schist complex, a sequence of Upper-Proterozoic metasediments, amphibolites, as well as syn-to-latetectonic porphyritic granites, charnockites, granodiorites, syenites and recent alluvium (Figure 1).

The migmatites and gneisses occur as a polycyclic basement, on which the rocks of Igarra Schist belt were unconformably deposited. The metasediments, comprising phyllite schists, quartz-muscovite-biotite schists, calc-silicate gneiss, quartzites, marbles, metaconglomerates are structurally overlying the mica schist unit and probably have been deformed at least twice during the Pan African Orogeny $550 \pm 50$ my (Odeyemi, 1982). The plutons of granite, granodiorite, tonalite, and the dykes of syenite which truncate both the migmatite gneiss basement and the metasupracrustal rocks, mark the termination of Precambrian activity in this area Rahaman, (1976). The rocks are suitable for small scale or large scale mining and have been used elsewhere for industrial minerals, production of roofing sheets, animal food in poultry and non-fuel mineral resource (Barton, 1968, Minnes et al., 1983, Carvalho et al., 2008, Hora 2007, Sutphin and Orris 2007, Ashmole 2004). Presently, some of these rocks are being quarried into aggregates for construction purposes such as houses, roads, bridges and also powdered for industrial minerals and rocks in production of cement and poultry products. This paper is an attempt to identify the rocks that are suitable for dimension stone production in addition to the present uses as aggregates and powdered industrial minerals.

This article is published under the terms of the Creative Commons Attribution License 4.0

Author(s) retain the copyright of this article. Publication rights with Alkhaer Publications.

Published at: http://www.ijsciences.com/pub/issue/2018-01/

DOI: 10.18483/ijSci.1398; Online ISSN: 2305-3925; Print ISSN: 2410-4477 


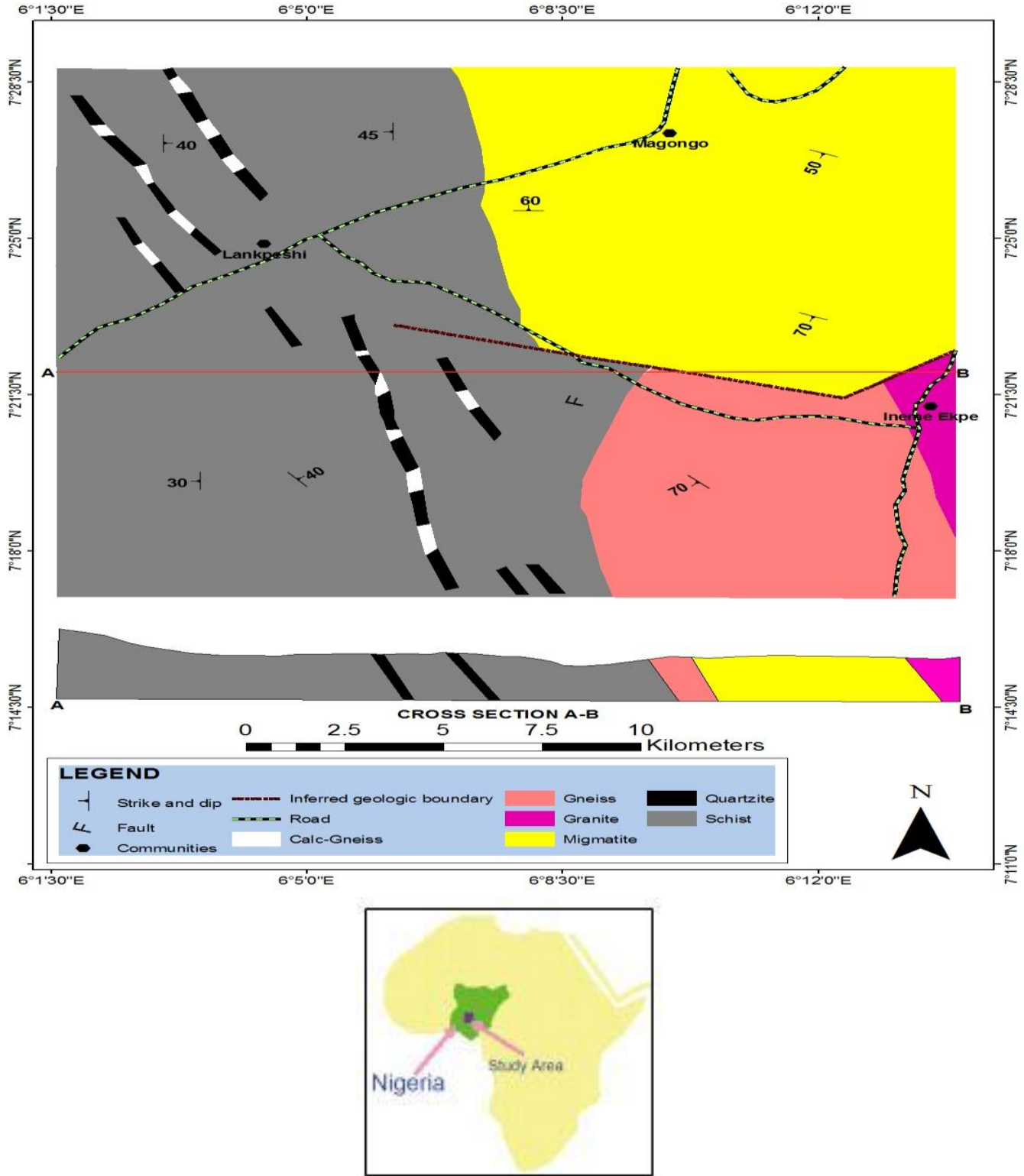

Figure1: Geologic map of Lankpeshi part of Igarra area (Megwara, 2016)

\section{LOCAL GEOLOGY}

The different rock types are granites which are massive dome-like features about $570 \mathrm{~m}$ to over $600 \mathrm{~m}$ at Somorika and Ososo areas while the granite gneisses are less massive. The marbles are covered with about $1 \mathrm{~m}$ of superficial deposits in Bekuma, the boundary area between Kogi and Edo states along Lankpeshi - Ososo road. Deposition of rocks for processing into crushed rocks and dimension stone are largely associated with internal processes which take place at variable depth within the Earth at high temperature high pressure and low pressure high temperature and are largely associated with igneous and metamorphic rocks being, gradually exposed to the surface by the processes of denudation Egesi and Tse (2011). Crushed rock aggregates and dimension stone are generally easily obtainable in areas underlain by the Basement Complex rocks, which underlies roughly one half of the area of Nigeria in the southwest, northcentral and southeast of Nigeria. Igarra area fall within southwest section. Geology is so important to us that it touches every aspect of our lives. On daily, weekly and monthly basis, we use million of tonnes of aggregates rocks to build our houses, towns and cities, roads and airports Egesi and Ukaegbu, (2013).

\section{EXPLORATION AND PRODUCTION}

Exploration for rocks suitable for dimension was carried out through detailed field mapping and petrographic studies. The ability of geoscientists to match types of mineral deposits with particular geological situations is the basis of mineral exploration. Most mining in Nigeria, such quarrying are on large, small-scale or artesinal basis. Records of aggregate production data can be obtained from the 
Crushed Rocks and Dimension Stone: Exploration, Evaluation and Exploitation in parts of Igarra Area, Southwestern Nigeria

Mines Department of Ministry of Solid Minerals Development. However, production data of dimension stone are scare or non-existent. Adequate deposits of rocks for crushed rock aggregates are present at Igarra town, Somorika, Ogugu, Bekuma, Igue Oke, Ojah, Ossoso, Ikpeshi, Iyuku and Imeke areas. The schist at Octopol quarry near Igarra is not suitable for dimension stone (Fig. 2, 3, and 4a). The petrography of the rock indicate mica, hornblende, feldspar and quartz with parallel alignment of schistose minerals mica and hornblende (Fig. 4b), while the granite is suitable Fig.5a and b. Table 1 is showing the dry unweathered rock which also a factor in the selection of rocks for dimension stone production.

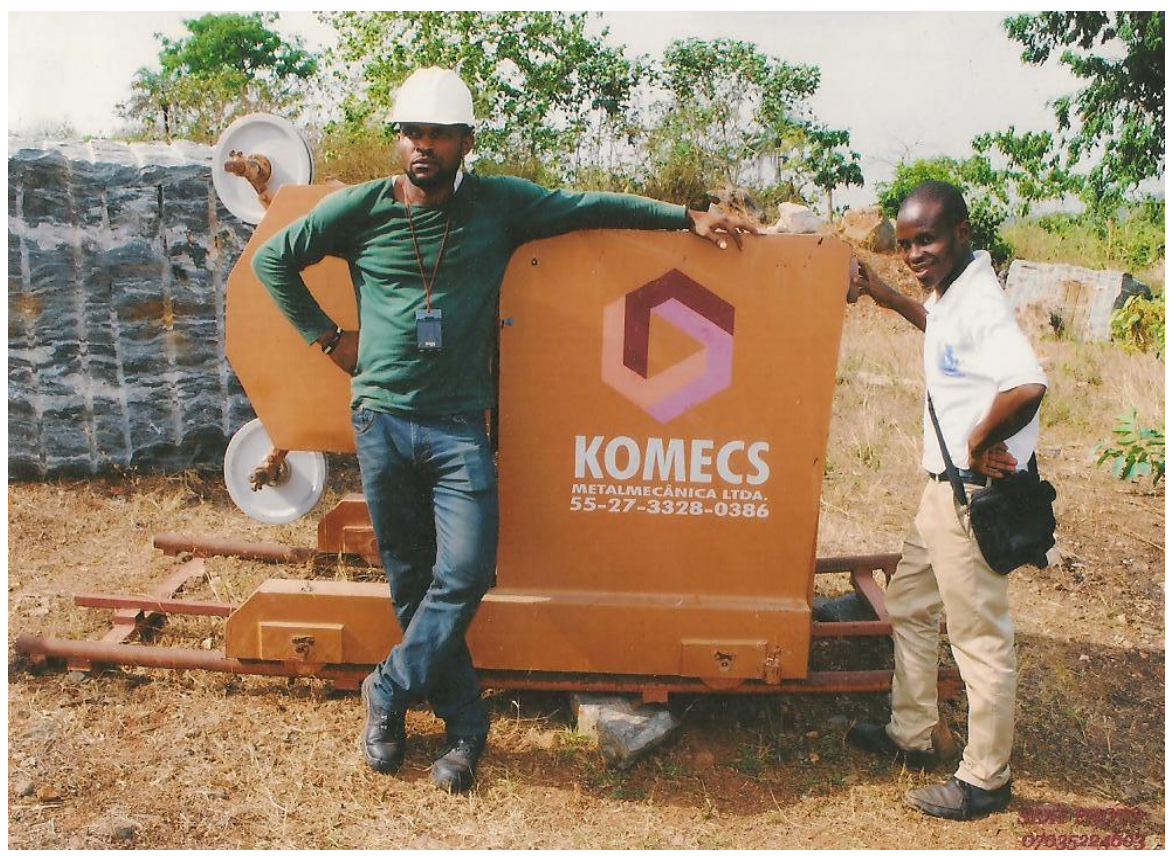

Figure 2 Field Photograph of Dimension stone cutting machine abandoned at Octopol Quarry in Igarra area.

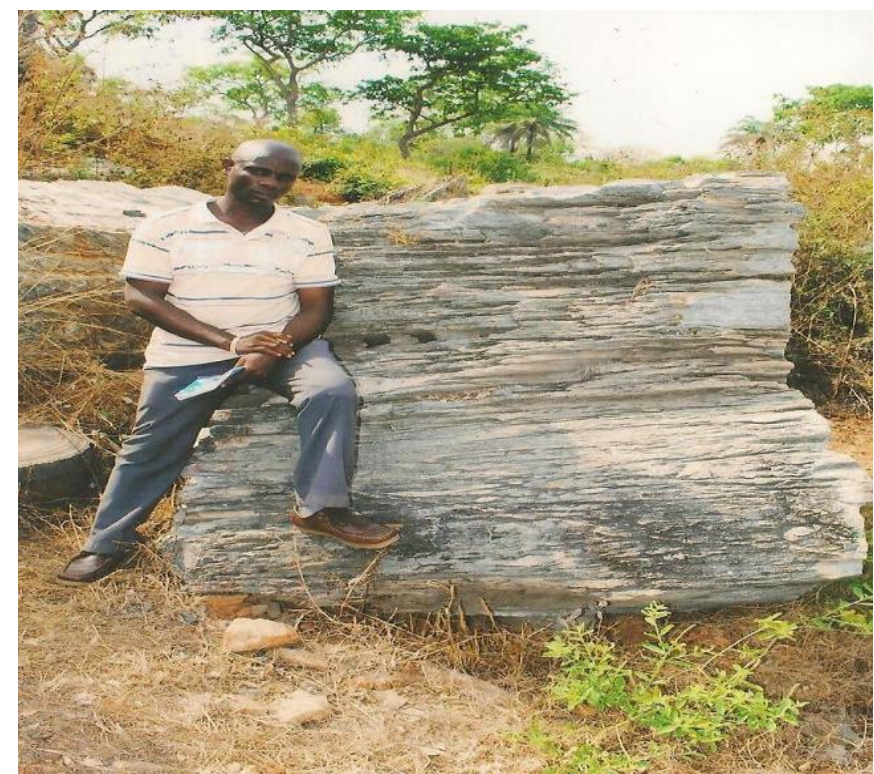

Figure 3. Field Photograph of a block of quartz biotite schist cut-out for Dimension stone production at Octopol quarry Igarra area. 
Crushed Rocks and Dimension Stone: Exploration, Evaluation and Exploitation in parts of Igarra Area, Southwestern Nigeria

TABLE 1. Typical unit weights for various dry unweathered rocks $\left(\mathrm{KNm}^{-3}\right) \min$ or max $=$ unlikely to be less or more than mean $=$ most frequently, $\mathrm{N}=$ no value can be recommended $=$ unknown .

\begin{tabular}{|l|l|l|l|l|}
\hline Rock Type & Min & Common Range & Mean & Max \\
\hline Granite & 23.7 & 25.1 to 27.6 & 26.8 & 29.2 \\
\hline Syenite & 24.6 & 25.1 to 26.7 & 25.8 & 28.3 \\
\hline Diorite & 26.7 & 26.7 to 28.3 & 26.8 & 29.8 \\
\hline Gabbro & 26.7 & 28.9 to 29.8 & 29.5 & 30.1 \\
\hline Porphyry & 23.1 & 23.4 to $N$ & 24.8 & 28.1 \\
\hline Dolerite & 25.4 to 27.6 & 27.1 & 28.1 \\
\hline Rhyolite & 22.5 & $\mathrm{~N}$ & $\mathrm{~N}$ & 26.8 \\
\hline Andesite & 19.5 & 21.7 to 22.5 & 27.1 & 26.8 \\
\hline Basalt & 19.5 & 25.1 to 27.5 & $\mathrm{~N}$ & 27.9 \\
\hline Gneiss & 22.0 & 25.4 to 26.8 & $\mathrm{~N}$ & 27.6 \\
\hline Schist & 23.8 & 26.7 to 27.6 & $\mathrm{~N}$ & 27.9 \\
\hline Slate & 18.2 & 27.3 to 28.3 & 26.8 & $\mathrm{~N}$ \\
\hline Marble & 26.5 & 26.7 to 27.6 & & 28.4 \\
\hline
\end{tabular}

(Source: Blyth and de Freitas, 2005)

\section{EVALUATION}

Effective dimension production requires evaluation of the deposit. The area has been mapped with regional aeromagnetic surveys and remote sensing studies. However, the individual deposits requires evaluation to determine the best method for production design. Presently, the operators of small scale mines depends on manual digging, drilling two meters hole, blasting and excavation of products. The use bench mining will be effective and reduced the indiscriminate opening of the ground surface causing badland topography without any reclamation project in in view.

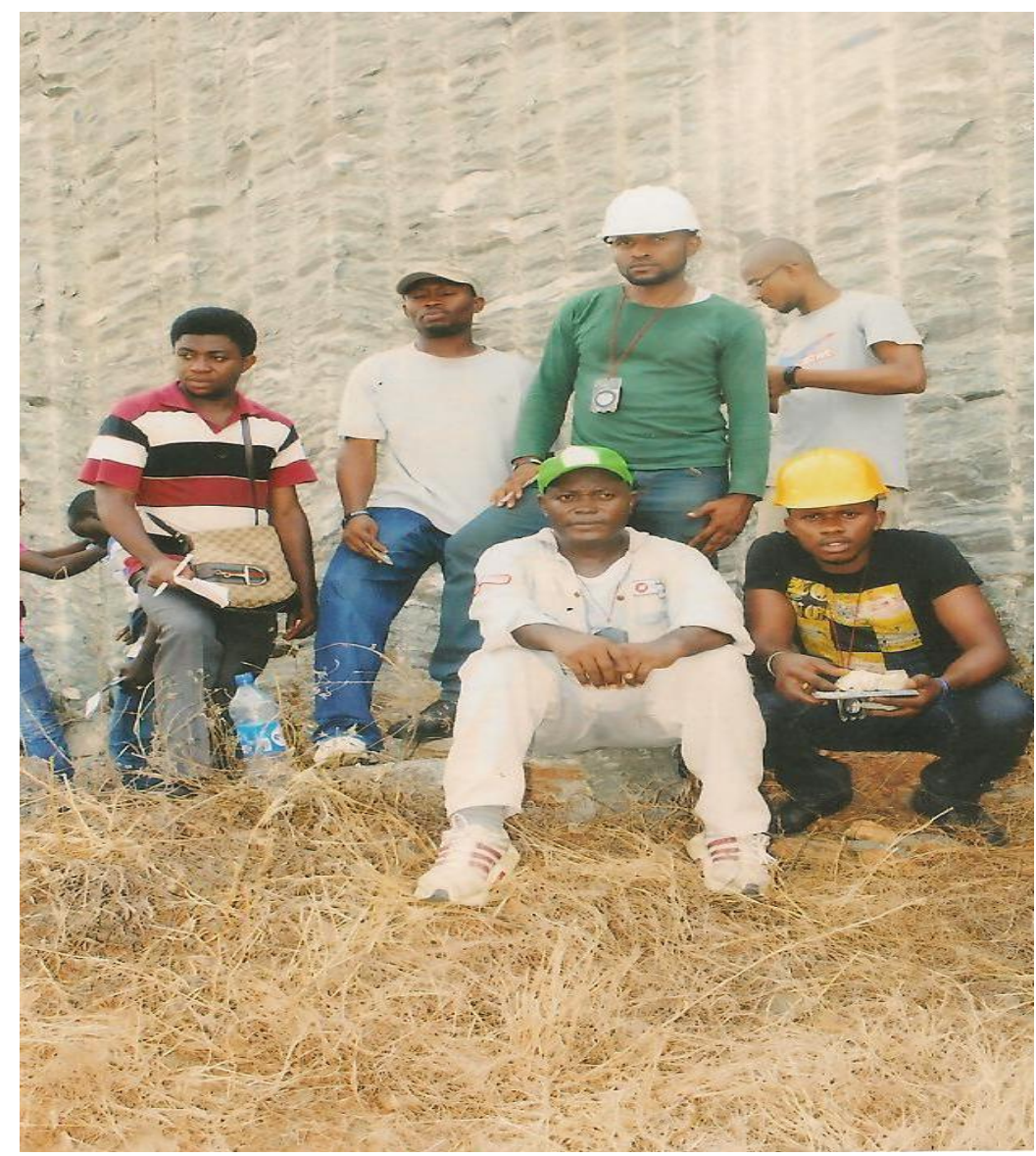

Figure 4a. Field Photograph of a face of quartz-biotite schist showing squared drilling pattern at Octopol quarry in Igarra area. 
Crushed Rocks and Dimension Stone: Exploration, Evaluation and Exploitation in parts of Igarra Area, Southwestern Nigeria
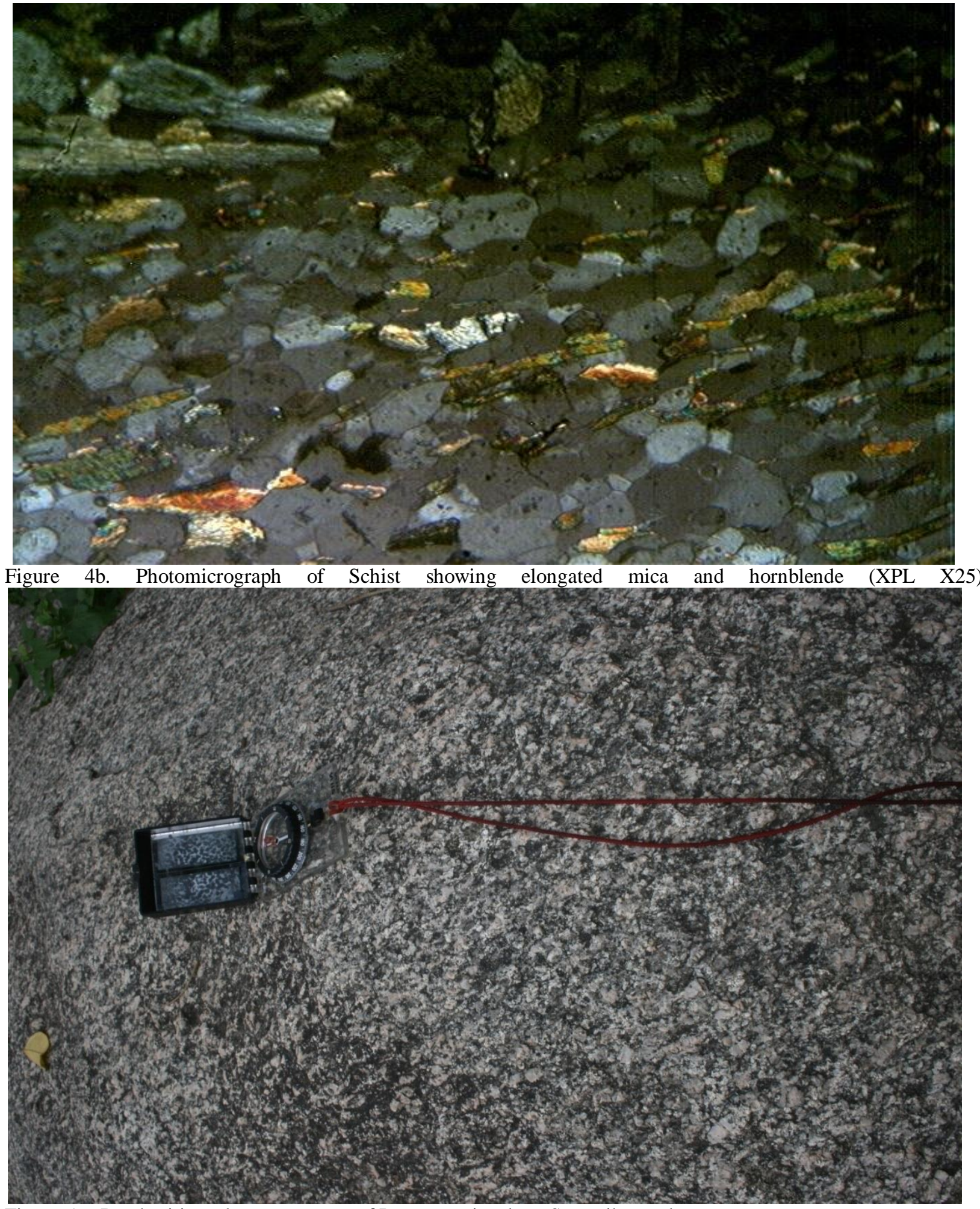

Figure 5a. Porphyritic and coarse texture of Igarra granite along Somorika road. 
Crushed Rocks and Dimension Stone: Exploration, Evaluation and Exploitation in parts of Igarra Area, Southwestern Nigeria

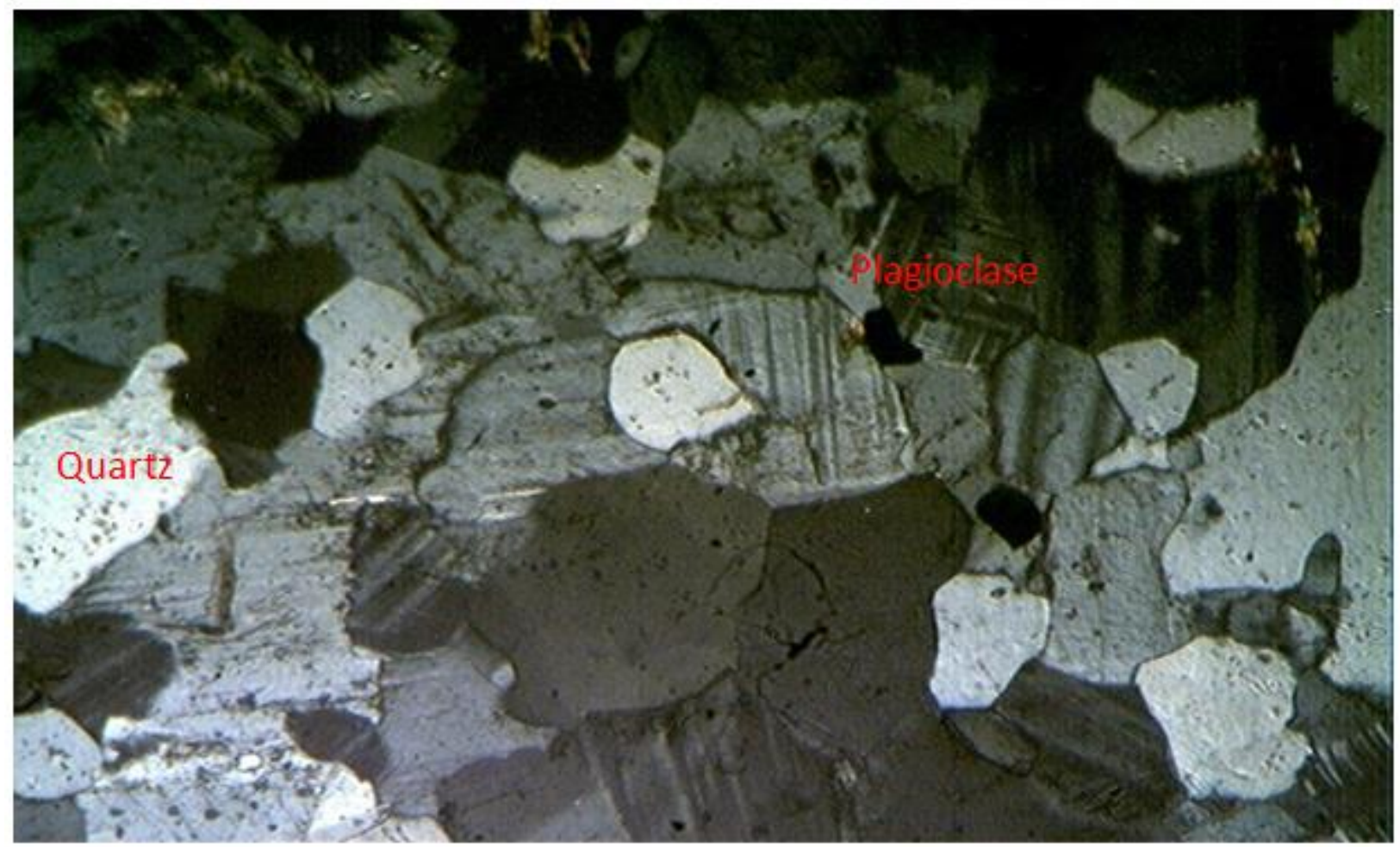

Figure 5b. Photomicrograph under cross polar of a granite showing interlocking grain boundary of quartz and feldspar minerals in Igarra granite

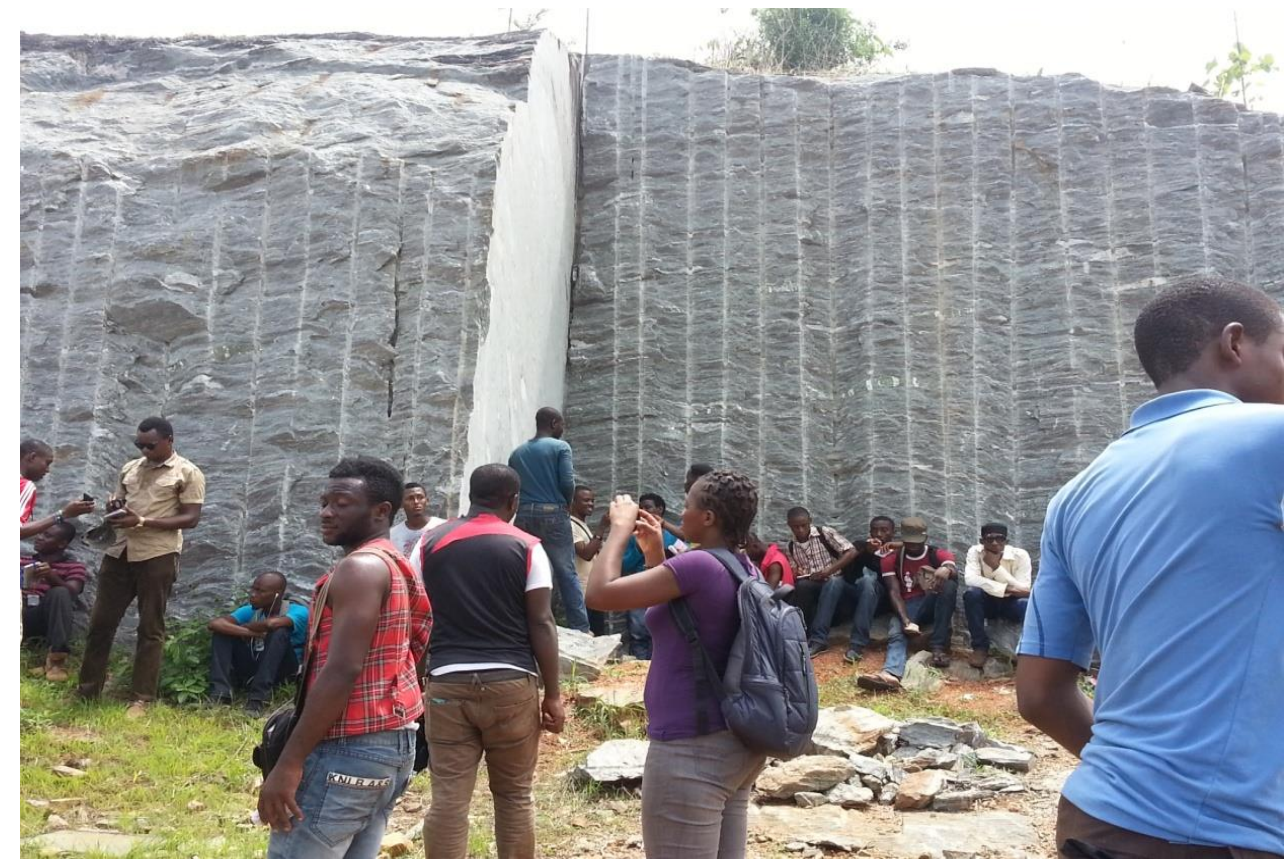

Figure 6 Field Photograph of Students on cut face of quartz-biotite schist in Igarra. 
Crushed Rocks and Dimension Stone: Exploration, Evaluation and Exploitation in parts of Igarra Area, Southwestern Nigeria

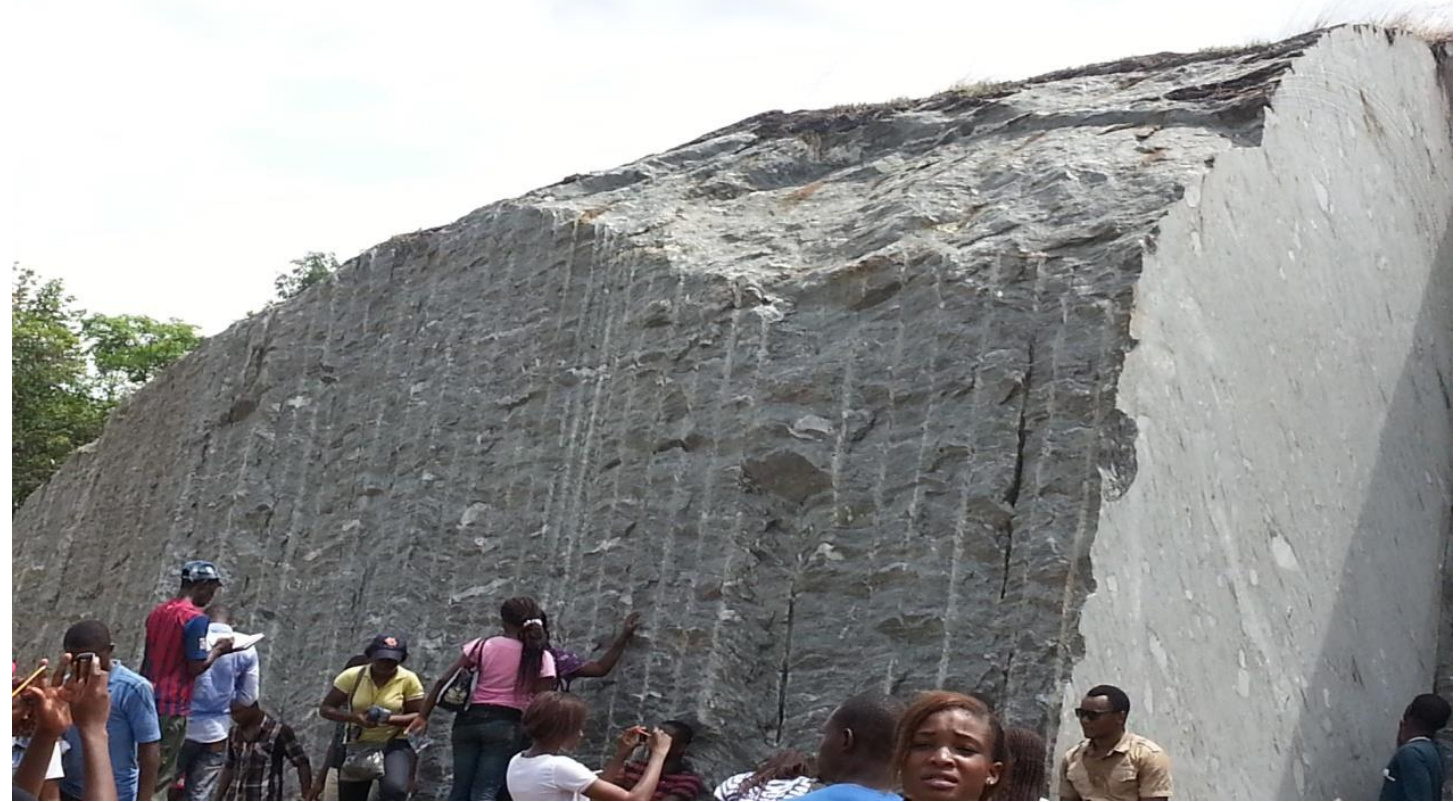

Figure 7. Field Photographs showing measurements on face of quartz-biotite schist in Igarra.

The rocks formed from contact metamorphism of limestone are of two types the light colour marble and black colour calc-silicate varieties. They are coarse texture which was due to the degree of heating and prolonged period of metamorphism. Figures 8 and 9 are field photographs of white coloured or pure marble which are valued by sculptors at Bekuma, while Figure 10 is dark coloured marble or calc- silicate rock about $1 \mathrm{~km}$ from the white coloured type Lankpeshi - Ossoso road Akoko Edo area. The processing of the rocks are made with jaw crusher, blower and baggage in fifty kilogram bag for sale to cement, roofing sheets and poultry feeds production factories in different parts of the country (Figs. 11 and 12).

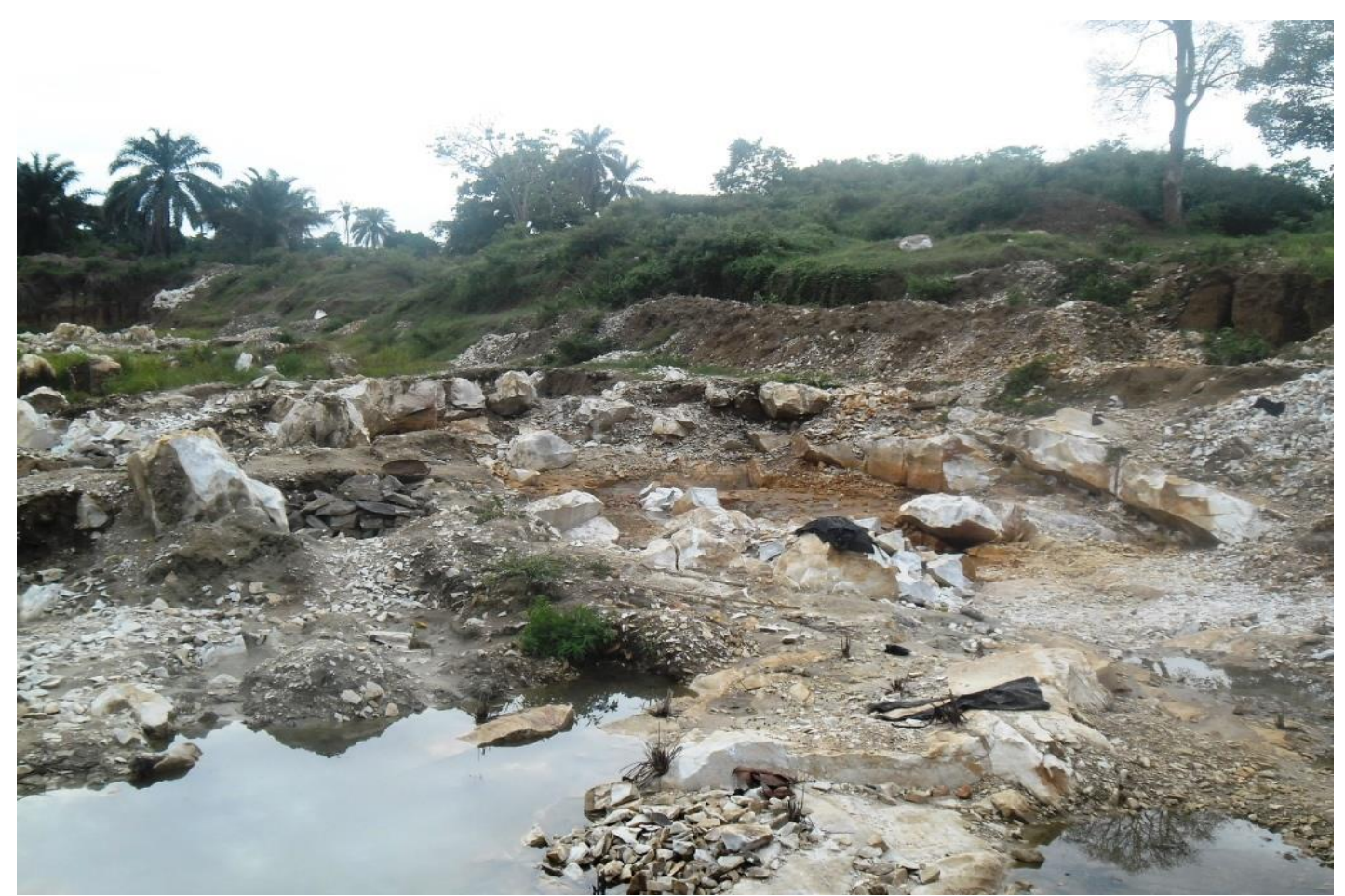

Figure 8a Top and 8b Below. Field Photograph of a mining pit of marble looking a badland topography at Bekuma Kogi/Edo state boundary along Lankpeshi/Ossoso road. 
Crushed Rocks and Dimension Stone: Exploration, Evaluation and Exploitation in parts of Igarra Area, Southwestern Nigeria
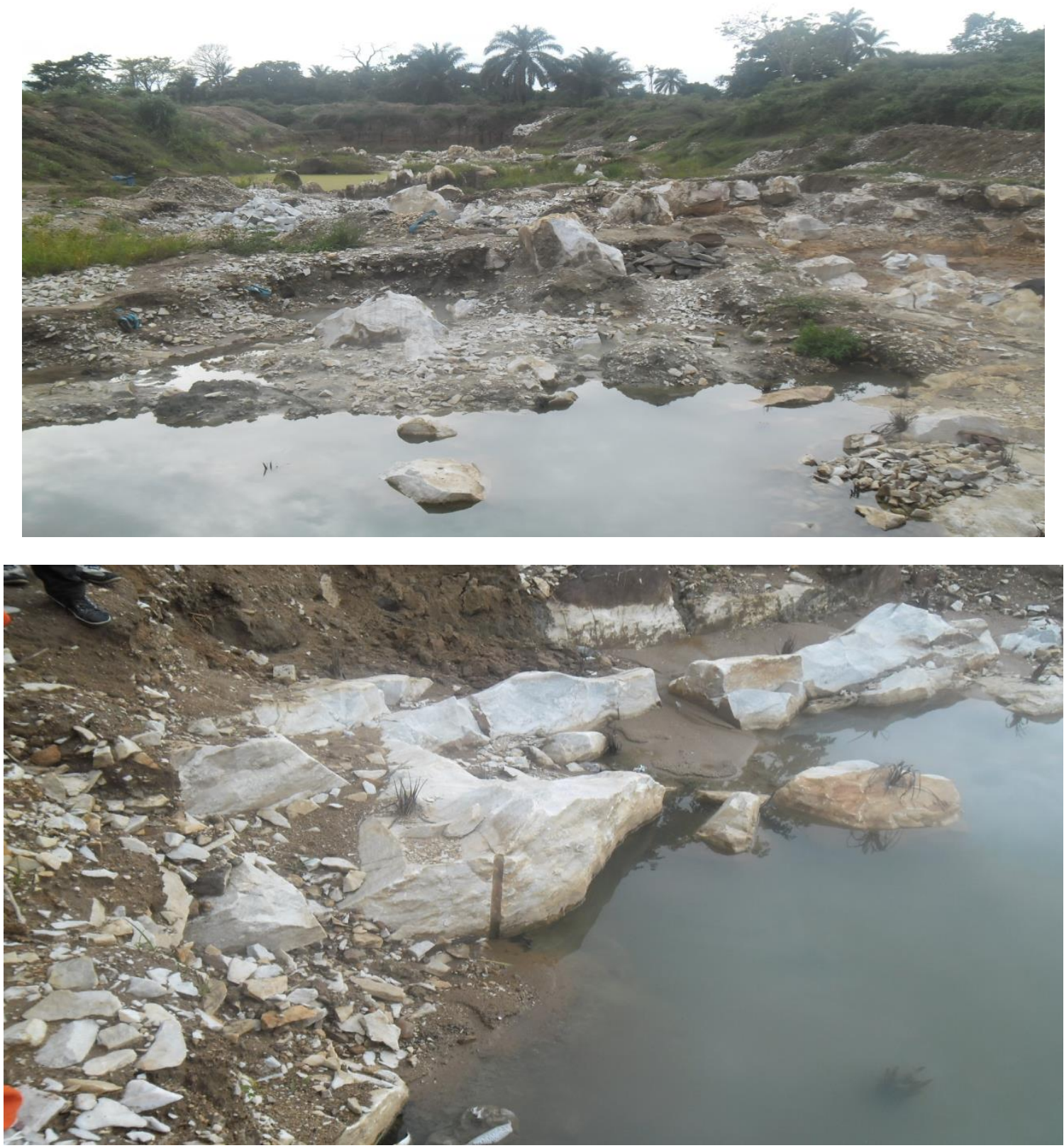

Figure $9 \mathrm{a}$ and $\mathrm{b}$. Field Photograph of aggregates and boulders being excavated before haulage to processing plant and a fresh face for blasting at Bekuma near Lankpeshi area. 
Crushed Rocks and Dimension Stone: Exploration, Evaluation and Exploitation in parts of Igarra Area, Southwestern Nigeria

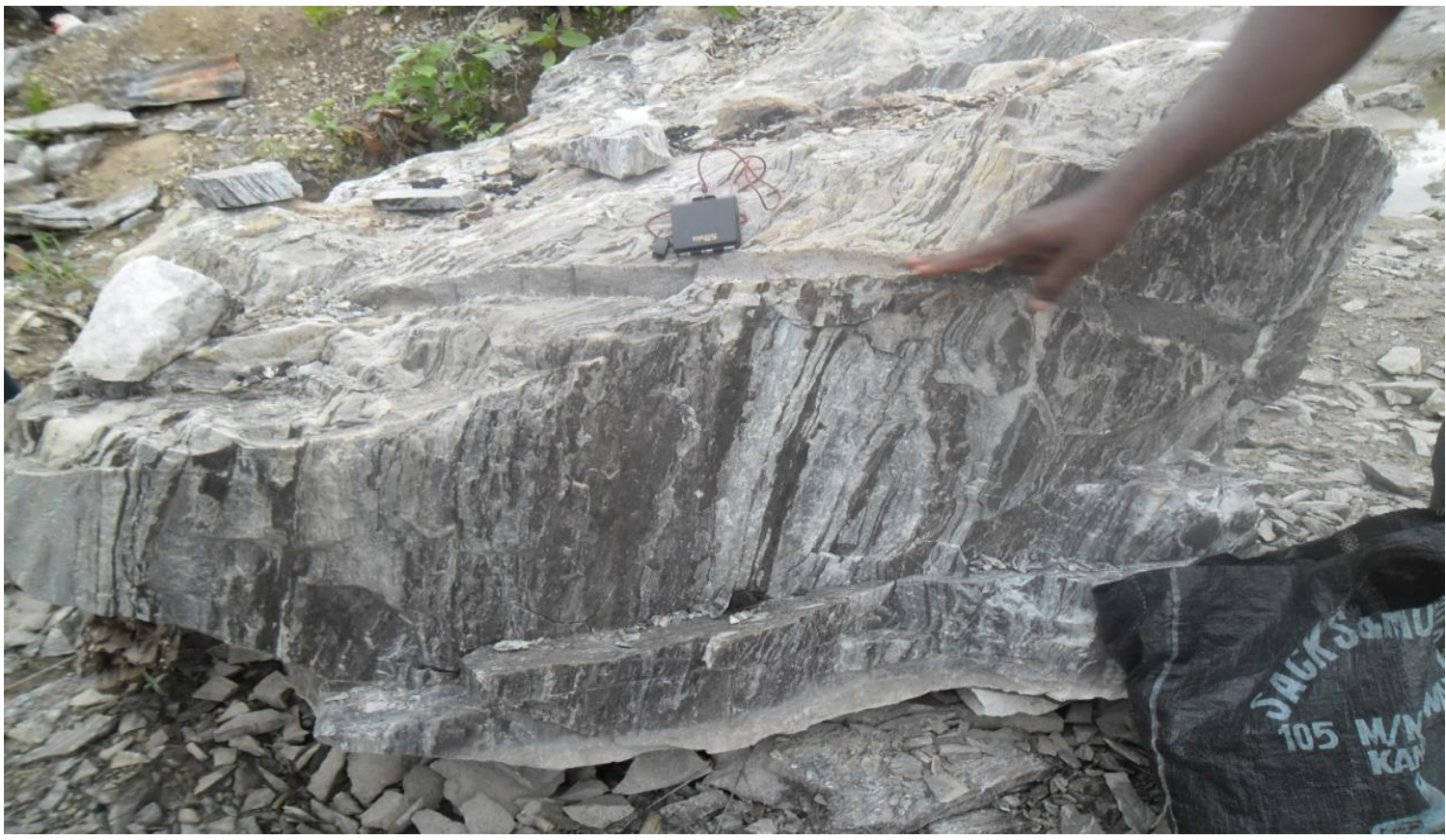

Figure 10. Field Photograph of showing boulder of Calc-silicate about $1 \mathrm{~km}$ opposite the pure marble site at Bekuma along Lankpeshi-Ossoso road Edo State.

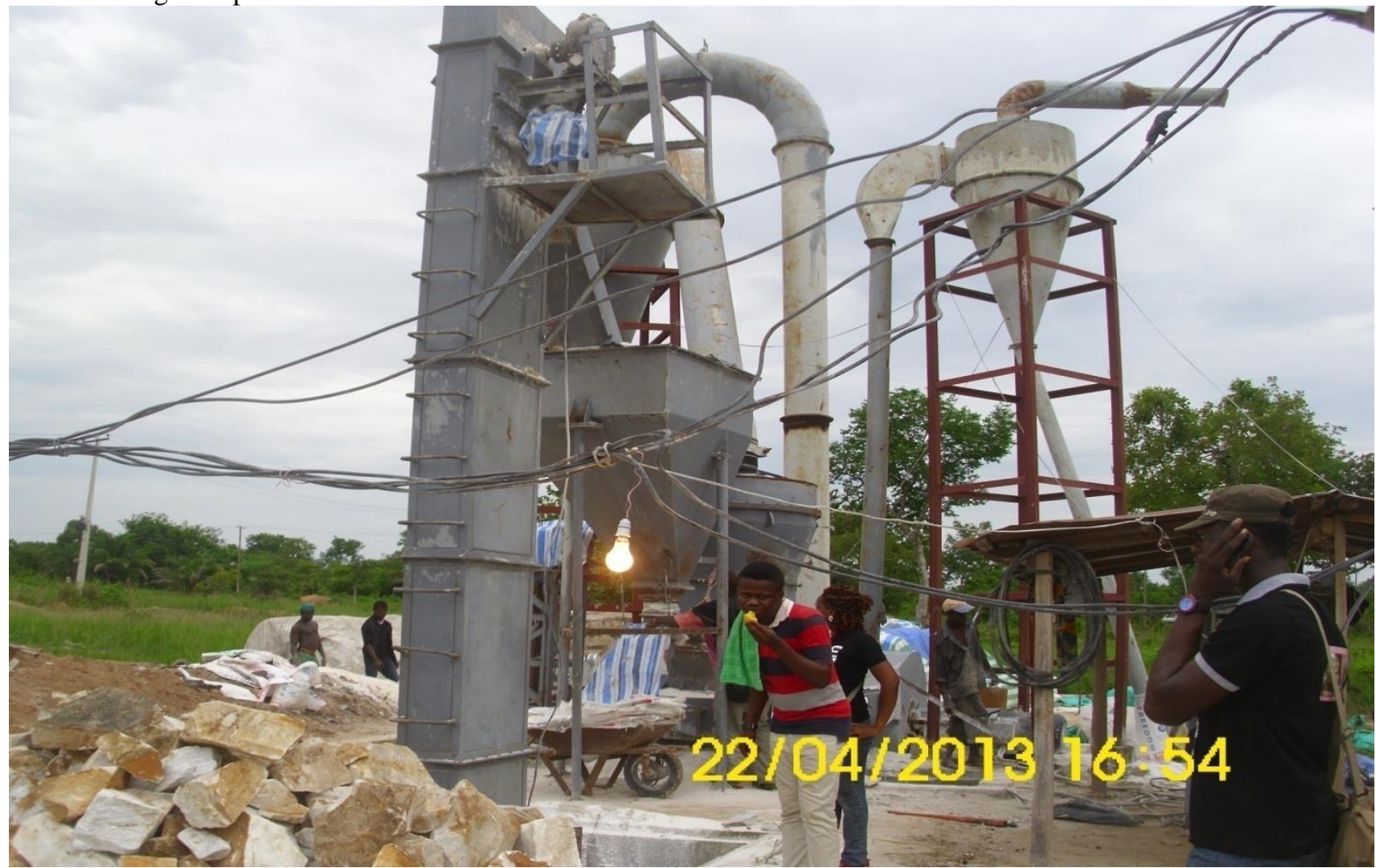

Figure 11a. Processing Plant with different components of jaw crushers, blower and baggage component at Bekuma Edo State. 
Crushed Rocks and Dimension Stone: Exploration, Evaluation and Exploitation in parts of Igarra Area,

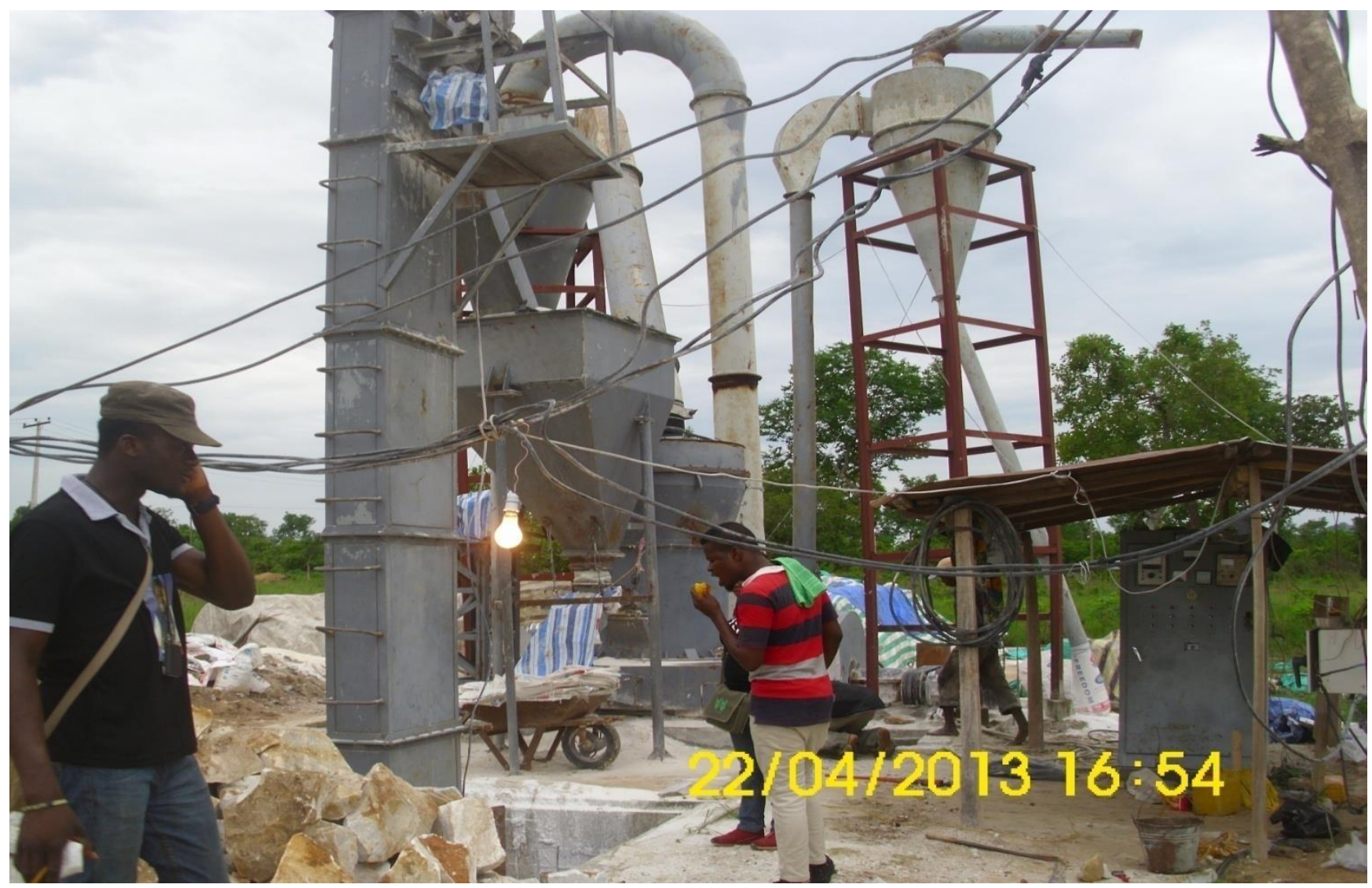

Figure $11 \mathrm{~b}$. The control panel with a shade indicates performance of the different parts of the processing plant

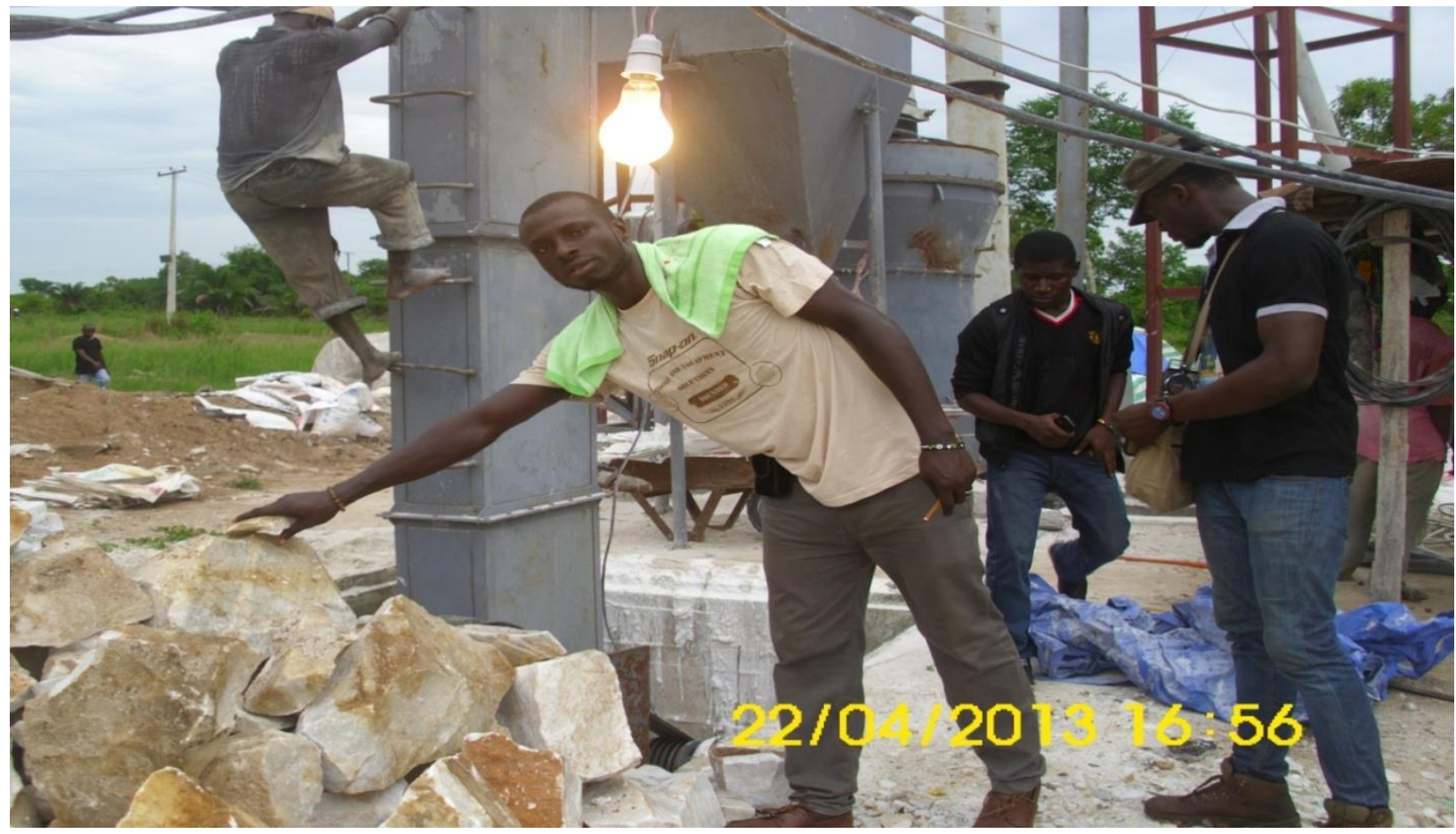

Figure 12 Field Photograph showing boulders of marble before introduction into the jaw crusher at the base processing plant Bekuma, Edo State.

\section{DISCUSSION}

Exploration, evaluation and production of rocks for dimension stone should involve geoscientists to reduce cost of selecting wrong site Egesi and Tse (2011). Petrographic studies should form part of exploration and evaluation process, this was not the 
case at Octopol quarry in Igarra area. There is need to integrate mine reclamation to these quarrying operations as the mined out areas tend to become bad land topography if the mining pit is not reclaimed. Merki (2000) observed that sustainable development of natural stone industry will include mitigating the impact of mining on the environment. This is important and should be part of any quarry development plan either in small scale or large scale operations in parts of the Igarra area and other parts of Nigeria where extraction of rocks and mineral resources are in progress. The Mines Department of Federal Ministry of Solid Minerals Development should have a section that could help small- and medium- scale enterprises (SMEs) that are unable to facilitate good land reclamation projects.

\section{CONCLUSION}

It should be noted that power is a very important part of the dimension stone production in the quarry industry. All appropriate measures should be made to reduce cost of the energy utilized in the production of cut and polished stones as these factors affect the cost of the final product. The Octopol quarry was abandoned due to the mineralogy of the schist, probably the petrographic analysis of the rock was not made to ascertain the quality of the rock before embarking on production. However, granites, granite gneisses, charnockites and marbles present in the area will be suitable for dimension stone production based on interlocking grained boundaries. The varieties of marble for decorative stones should not be clean with wet cloth because of reaction to form a weak acid which attacks the polished surface and decolourize it to a dull and uninteresting surface. Small- and medium- scale enterprises (SMEs) should be encouraged to invest in dimension stone mining to reduce dependence on imported and finished products.

\section{REFERENCES}

1. Annor, A. E. (1998). Structural and Chronological relationship between the low grade Igarra schist and its adjoining Okene migmatite-gneiss terrain in the Precambrian exposure of SW Nigeria. J. Min. Geol., 34 (2): 187 - 194.

2. Ashmole, I. (2004) "Dimension Stone: The Small Scale Mining Potential in South Africa", Paper presented at Small Scale Mining 2004, Johannesburg, 9 September 2004.

3. Barton, W.R. (1968) Dimension stone: U.S. Bureau of Mines Information Circular 8391, 147 p.

4. Blyth, F. G. H. and de Freitas, M. H. 2005. A Geology for Engineers. $7^{\text {th }}$ Edition, p.166.

5. Carvalho, J.F., Henriques, P., Fale, P., Luis, G. (2008) "Decision criteria for the exploration of ornamental-stone deposits: Application to the marbles of the Portuguese Estremoz Anticline", International Journal of Rock Mechanics and Mining Sciences (2008), doi:10.1016/j.ijrmms.

6. Egesi, N. and Tse, A. C. (2011) Dimension stone: Exploration, Evaluation Exploitation in southwest parts of Oban Massif, southeastern Nigeria, Journal of Geology and Mining Research vol 3(4), pp115-122.
7. Egesi, N. and Ukaegbu, V. U. (2013) Dimension Stone and Deveolpment in Boki Area Southeastern Nigeria. J. Appl. Sci. Environ. Manage. Vol. 17 (3) 343 - 354

8. Geological Survey of Nigeria (GSN) 1986. Instruction to authors of reports Bulletin.

9. Jones HA, and Hockey RD (1964). The Geology of part of Southwestern Nigeria; Geological Survey of Nig. Bull, 31: 101-104.

10. Hora, Z.D. (2007) 'Dimension Stone "Marble" RO4", in Selected British Columbia Mineral Deposit Profiles, British Columbia Geological Survey, Victoria, B.C., Canada, 2007.

11. Megwara, V. I. 2016. Petrology and Structural Geology of Lankpeshi area of Igarra Schist belt, Southwestern Nigeria. Unpubd M.Sc Dissertation UPH.

12. Merke, G. (2000) Sustainable development in the natural stone industry", Roc Maquina, June 2000, pp 56-58.

13. Minnes, D.G, Lefond, J and Blair, R. (1983) Nepheline syenite, Industrial minerals and rocks, $5^{\text {th }}$ edition, AIME, New York, p981.

14. Odeyemi, I. B. (1976) Preliminary report on field relationships of the Basement Complex rocks around Igarra, Mid-West. In Geology of Nigeria. C. A. Kogbe (ed.) Lagos: Elizabethan Pub. Co., p. 59-63.

15. Odeyemi, I. B. (1982) Areview of the orogenic events in the Precambrian basement of Nigeria, West Africa. Geol. Rundsch., 70: 897 - 909.

16. Rahaman, N. M. (1976): Review of the Basement Geology of Southwestern Nigeria, in Geology of Nigeria edited by C.A Kogbe pp 41-58 Elizabethan Publ. Co. Lagos , Nigeria

17. Sutphin, D.M, and Orris, G.J., 2007 "Dimension Stone", in Preliminary Non-Fuel Mineral Resource Assessment of Afghanistan, Peters, S.G. et al (eds), United States Geological Survey Open-File Report 2007-1214, pp677-702. 